couplet to move forward so that any point on the surface of the leading cell traced out a helical path.

Hoffman and Frank discount the possibility that snapping movements are due to the action of flagella, which is strange when they claim to have worked with a motile strain and also state that the phenomenon was observed only in the transitional zone of the micro-culture system used $^{3}$ where there would be the necessary freedom of movement. In my own experiments there was complete facility for free-swimming as there was no pressure between membrane and cover-slip. Also, the four photomicrographs published might be misleading as problems of depth-of-focus would necessarily dictate that images were obtained only in one plane so that rotary action could not be recorded. Yet none of the recordings of these authors contradict the findings made by direct continuous observation, and are, in fact, wholly compatible with them, even in regard to the periods of rest during lashing activity which is recorded micrographically by the non-blurred image published in Fig. 4 of Hoffman and Frank's paper.

The reported observations would scem to indicate that the flagellation in this strain might be polar, yet Leifson ${ }^{4}$ reports that of several dozen strains of $E$. coli examined all were peritrichously flagellate, although some had very few flagella; moreover, these observations on motility fully confirm other well-cstablished views (see Weibull ${ }^{5}$, but we have yet to understand how peritrichously arranged flagella could drive bacteria in the unidirectional manner observed.

Department of Bacteriology,

LouTS B. QUESNEL

University of Manchester.

' Hoffman, H., and Frank, M. E., J. Bact., 89, 789 (1965).

"Quesnei, J. B., J. App. Bact., 26, 127 (1963).

s. Hoffman, H., and Frank, M, E., J. Gen. Microbiol., 25, 353 (1961)

"Leifson, E., Atlas of Bacterial Flagellation (Academic Press Inc., New

${ }^{3}$ Weibull, C., in The Bacteria, edit. by Gunsalus, I. C., and Stanier, 1 (Academic Press, 1960).

\section{Hydrocarbons as Substrates for Yeasts}

Markovetz and Kallio ${ }^{1}$ pointed out that the assimilation of hydrocarbons might be of value in the classification of yeasts. Komagata et al. ${ }^{2}$ found that fifty-six of 498 yeast strains belonging to twenty-eight genera were able to grow on kerosene as the sole source of carbon and energy. All strains except two belonged to the genus Candida. In several species some strains grew well on kerosene, while others did not. No growth on kerosene was observed with some species, which were able to assimilate pure hydrocarbons of the kerosene fraction according to other reports ${ }^{1,3}$.

Wc investigated whether the results for the assimilation of $n$-decane and $n$-hexadecane by various yeast species correspond with those on kerosene and, furthermore, whether the utilization of these hydrocarbons may be a specific property of the species. We tested 1,200 yeast strains of the culture colloction of the Centraalbureau voor Schimmelcultures. The 244 species represented by these strains belonged to the following genera: Saccharomyces (thirty-seven), Hansenula (twenty-one), Pichia (thirty), Debaryomyces (ten), Candida (fifty-four), Torulopsis (fifty-two), Brettanomyces (seven), Kloeckera (eight), Cryptococcus (ten) and Rhodotorula (fifteen).

For the preliminary screoning reported here the tech. nique of replica-plating was applied. Thirty eultures wero transferred to the initial plate, containing wort agar, and incubated at $25^{\circ} \mathrm{C}$ for 2 days. The basic medium for the tcsts was a mineral agar with B-vitarnins 4 .

To the sterilized basal agar, in which 0.25 per cent tanrocholate was incorporated for better emulgation, 1 per cont $n$-hoxadecane (99 per cent pure, Fluka) was addod. $n$-Decane (99 por cent pure, Fluka) and kerosene (normal Esso) were supplied as vapour. The plates were incubated at $25^{\circ} \mathrm{C}$ for 1 week. If strains of a spocies
Table 1. Number of STrains Assimirating n-HeXadeCane, n-DECANE AND KEROSENE IN SOME SPECIES OF Piehia, Debaryomyees, Torulopsis AND

\begin{tabular}{|c|c|c|c|c|}
\hline & Number of & Number & f strains gr & owing on \\
\hline Species & $\begin{array}{l}\text { strains } \\
\text { tested }\end{array}$ & $\begin{array}{c}n-\mathrm{Hexa} \\
\text { decane }\end{array}$ & $n$-Decane & Kerosene \\
\hline * Pichia farinosa & 22 & 22 & 22 & 19 \\
\hline $\begin{array}{l}\text { Pichia guilliermondii } \\
\text { * Pichia haplophila }\end{array}$ & 37 & 37 & 37 & 33 \\
\hline $\begin{array}{l}\text { * Pichia haplophila } \\
\text { * Pichia pastoris }\end{array}$ & 2 & 2 & 2 & 2 \\
\hline $\begin{array}{l}\text { *Pichia pastoris } \\
\text { * Pichia polymorpha }\end{array}$ & 2 & 2 & 2 & 2 \\
\hline $\begin{array}{l}\text { * Pichia polymorpha } \\
\text { * Pichia robertsii }\end{array}$ & 3 & 3 & 3 & 2 \\
\hline $\begin{array}{l}\text { * Pichia robertsii } \\
\text { *Pichia scolyti }\end{array}$ & $\frac{2}{5}$ & $\begin{array}{l}2 \\
1\end{array}$ & 2 & $\begin{array}{l}2 \\
1\end{array}$ \\
\hline * Pichia vini & 5 & 5 & 5 & 5 \\
\hline Debaryomyces hansenii & 45 & 45 & 45 & 45 \\
\hline * Debaryomyces vanriji & 4 & 4 & 4 & 4 \\
\hline *Torulopsis dattila & 2 & 2 & 1 & 1 \\
\hline *Torulopsis famata & 12 & 12 & $1 \overline{2}$ & 12 \\
\hline * Torulopsis haemulonii & 2 & 2 & 2 & 2 \\
\hline *Torulopsis saké & 2 & 1 & 1 & 1 \\
\hline *Candida brumptii & 6 & 6 & 5 & 4 \\
\hline * Candida catenulata & 5 & 5 & 5) & 1 \\
\hline Candida intermedia & 10 & 10 & 10 & 6 \\
\hline Candida lipolytica & 12 & 12 & 12 & 8 \\
\hline *Candida melinii & 4 & $\bar{l}$ & 1 & 1 \\
\hline Candida parapsilosis & 11 & 11 & 11 & 9 \\
\hline Candida pulcherrima & 17 & 16 & 10 & 11 \\
\hline Candida reqkaufti & 7 & 7 & 5 & 2 \\
\hline * Candida rhagii & 4 & 4 & 3 & 4 \\
\hline *Candida tenuis & 8 & 4 & 3 & 2 \\
\hline Candida tropicalis & 24 & 24 & 24 & 24 \\
\hline
\end{tabular}

* Species not previously known as hydrocarbon utilizers.

grew both on $n$-decane and $n$-hexadecane as well as on kerosene, one of these strains was retested in shaken cultures with 2 per cent of the same carbon sources.

In the genus Kloeckera no $n$-decane, $n$-hexadecane and kerosene assimilating strains were detected. A few of the Hansenula, Brettanomyces and Cryptococcus strains grew very weakly on $n$-hexadecano. In the genus Saccharomyces only the two strains of Saccharomyces elongasporus assimilated hydrocarbons readily, but the yeast differs from the typical species of this genus by a slow fermentation and the shape of the spores. In some Rhodotorula species $n$-decane-, $n$-hexadecane- and kerosene-utilizing strains occurred, but growth was very slow or weak; negative strains were found in the same species. Many strains, utilizing $n$-decane, $n$-hexadecane and kerosene, were detected in the genera Pichia, Debaryomyces, Candida and Torulopsis. Some of the results are shown in Table 1. The species not previously known as hydrocarbon utilizers are indicated by an asterisk.

Generally, growth on kerosene vapour was weaker than on the pure $n$-alkanes; sometimes no growth on kerosene was observed with strains assimilating $n$-decane and $n$-hexadecane. Some strains, which grew well on kerosene vapour, failed to grow in shaken cultures containing kerosene. This suggests that the absence of growth may be due to an inhibitory effect of some components of the kerosene, rather than to the inability of the yeast to attack the $n$-alkanes. The results with the shaken cultures containing $n$-decane and $n$-hexadecane paralleled those obtained on agar, but in liquid medium growth was often better with $n$-hexadecane. In many species all strains utilized the pure $n$-alkanes, indicating that this ability can be a characteristic feature of the species. However, the assimilation of $n$-alkanes by the strains of one species may vary from weak or latent to good. In species, where only some strains were found to assimilate $n$-alkanes, growth was generally poor.

Additional strains utilizing $n$-alkanes could probably be detected with test conditions more favourable to adaptation and selection.

\section{RAGNHILD SCHEDA} P. Bos

Centraalbureau voor Schimmelcultures and

Laboratory of Microbiology,

Technological University,

Delft, Holland.

'Markovetz, A. J., and Kallio, R. F., J. Bacteriol., 87, 968 (1964).

${ }^{2}$ Komagata, K., Nakase, T., and Katsuya, N., J. Gen. App. Microbiol. (Tokyo), 10,313 (1964).

s Wang, Hsiu-Yüan, and Schwar,, W. Z., Z. Allgem. Mikrobiot., 1, 223 (1961).

Lodder, J., and Kreger-yan Rij, N. J. W., The Yeasts, a Taxomomic Study (North-Holland Publishing (Oo., Amsterdam, 1952). 